\title{
The Twenty-Second Annual Conference of the AMSS
}

\author{
$28 \mathrm{Rabi}^{\star}$ al Ākhir-1 Jumādā al Awwal 1414 / 15-17 October 1993 \\ International Institute of Islamic Thought, Herndon, Virginia
}

The Twenty-Second Annual Conference of the Association of Muslim Social Scientists (AMSS) was jointly organized by the International Institute of Islamic Thought (IIIT) and the AMSS and was held at the IIIT premises in Herndon, VA. The open-theme conference featured eighteen panels organized into fourteen sessions.

The opening session consisted of the welcoming address by Dilnawaz Siddiqui, President (Clarion University of Pennsylvania, Clarion, PA), remarks by Mushtaqur Rahman, Conference Chairman (University of Iowa, Ames, IA), and the inaugural address of Tāhā al 'Alwānī (President, IIIT). The second session, "Islamic Philosophy and Comparative Approaches," was chaired by Ja'afar Sheikh Idris (Institute of Islamic and Arabic Sciences, Fairfax, VA). Presentations included "Islamic Theory of Knowledge: A Reappraisal" by Sirajul Husain (Islamic Research and Development Council, Cleveland, $\mathrm{OH}$ ), "Islamization of the Creative Imagination and Its Ramifications in the Visual Arts of Islam" by Halide A. Salam (Radford University, Radford, VA), and "The Concept of Free Will in the Comments of al Ash"ari, al Hilli, and Taftazani" by Anne E. Francisse (Seattle, WA).

The third session had two concurrent panels: "Concept of Shürā and Democracy in Islam," chaired by Mumtaz Ahmad (Hampton University, Hampton, VA) and "Culture and Communication," chaired by Ali Ramadan (IIIT). The first panel comprised Aziza al Hibri (University of Richmond, Richmond VA) and Ja'afar Shaikh Idris. Al Hibri pointed out that shūrā (mutual consultation) is part of Islamic constitutional theory and reflects the divine dimension of an Islamic political framework - while democracy is one process of shürā reflecting the human will in the political plane. Also featured was Hamid al-Ghazali (Islamic Center of Lawrence, Lawrence, MO), who gave a special report on the removal of an unjust leader from an Islamic institution that had been presented to the Circuit Court of Jackson County, Missouri.

The culture and communication panel had three presentors. Sharaf Rahman (Northem State University, Aberdeen, SD) spoke on media types and Muslim culture vis-à-vis Pakistani films and videos. Hussein Abiva (Chicago, IL) dealt with the role and importance of Sufi orders in Balkan 
religious life, and Suleman Dangor (University of Durban-Westville, Durban, South Africa) discussed the expression of Islam in South Africa.

The fourth session, "Islam in the West," was chaired by Sayyid M. Syeed (General Secretary, IIIT). Muhammad Abbas, Ahmed Bin Yousef, and Ahmad AbulJobain, all from the United Association for Studies and Research (Washington, DC), presented "Muslim Social Scientists and Western Theory," "The Islamic Revival and Western Denial," and "Media Agenda Strategy: Chasing a Fundamentalist Chimera," respectively. Abbas presented a survey of writings on development and the Middle East and criticized Muslim social scientists for evasively abstract and defensive writings. Yousef stressed the need for civilized discourse between Islamists and western leaders and scholars. He also called for western acceptance of political Islam as a legitimate and potentially progressive system of beliefs and practices as opposed to the current distrust and antagonism. AbulJobain analyzed media demonization of Islam and gave examples of stereotyping, nonobjectivity, and double standards. Farrukh Hakeem (City University of New York, New York City, NY) urged Muslims living in the West to be good examples and exhibit the dynamism of Islam.

The second day began with "Islam in the American Media: Reporting, Reaction, and Responses," chaired by Jamal Barzinji (Trustee, IIIT). Four presentations were made: "The Portrayal of Pakistan in the Mainstream American Media" by M. M. Ali (University of the District of Columbia, Washington, DC), "Islamist Movements in the Arab World: The Los Angeles Times and the Christian Science Monitor" by Greg Noakes (Advertising Director, Washington Report on Middle East Affairs), "The Cultural and Political Divide between the United States and the Muslim World" by Ambassador Andrew Killgore (Publisher, Washington Report on Middle East Affairs), and "Strategy for a Muslim Response to Their Coverage in American Media" by Robert Hurd (Information Services Department, AMIDEAST, Washington, DC).

The sixth session had three concurrent panels: a roundtable on "The Fundamentalist Elephant and the Blind Men: The Quest for a Name and Definition," moderated by Salahuddin Malik (State University of New York, Brockport, NY), "Muslim Identity in America," chaired by Ilyas Ba-Yunus (State University of New York, Cortland, NY), and "Case Studies: Muslim Education," chaired by M. A. W. Fakhri (Chicago State University, Chicago, IL).

The roundtable opened with an introduction by Assad Busool (American Islamic College, Chicago, IL), who spoke on Islamic fundamentalism. He pointed out the term's Christian roots, as well as its absence from Islamic terminology, and explained the Islamic worldview: freedom of conscience; harmony of race, color, language, and creed; and its democratic 
values and principles. This, he suggested, was also the Muslim "fundamentalist" worldview. Sulayman Nyang (Howard University, Washington, DC) posited that fundamentalism is seen as a challenge to liberal secular concepts and values because the latter views only human (as opposed to transcendental) values as having relevance. Moreover, fundamentalism is viewed as a threat to the source of western wealth-hence the opposition. Mumtaz Ahmad (Hampton University, Hampton, VA) discussed different strands of thinking in contemporary Islamic thought as classified by westem scholarship-orthodoxy (or traditionalism), modernism, and reformism (or fundamentalism) - and noted that "fundamentalism," when used with hostile political connotations, as has often happened since 1979, is strongly disliked by Muslims. Henry Schuller (Center for Strategic and International Studies, Washington, DC) explained the American view of fundamentalism: undermining democracy, ignoring human rights, and anti-American. If Islamic movements call for democratic governance, tolerance, human rights, and respect for the rights of minorities and women, he said, then Islam, as a liberal faith, can be worked with.

The "Muslim Identity in America" panel had three speakers. Ihsan Bagby (Islamic Resource Center, Tustin, CA) spoke on the problems, needs, and priorities of Muslim communities, while Majed Khader (Marshall University, Huntington, WV) analyzed Muslim efforts to overcome obstacles in their quest for recognition and respect. Hussein Kassim (University of Central Florida, Orlando, FL) explored the prospects and possibilities of good relations among American Jews, Christians, and Muslims.

The "Muslim Education" panel featured M. A. W. Fakhri (Chicago State University, Chicago, IL), who spoke on the Open Islamic University and looked into its prospects for success. Shabir Mansouri (Council on Islamic Education, Fountain Valley, CA) documented the misrepresentation of Islam in school textbooks and pointed out the efforts, some of them successful, by the council to deal with this problem.

The seventh session consisted of "Acculturation of Muslims by the Western Media," chaired by Sulayman Nyang, "Issues and Models in Islamic Economics," chaired by Mohieldin Attia (IIIT), and "Women in Islam: Past and Present," moderated by Afeefa Syeed (University of Maryland, College Park, MD). In the first panel, papers were read by Yvonne Haddad (University of Massachusetts at Amherst, Amherst, MA) on challenges facing Muslims vis-à-vis the American media, by Dilnawaz Siddiqui on western communication theories and their practical models, and by Nadir Muhsin (St. Cloud University, St. Cloud, MN) on the media's promotion of intellectual indoctrination and intellectual terrorism.

The."Islamic Economics" panel was next. M. Siddieq Noorzoy (University of Alberta, Edmonton, AB, Canada) outlined the framework for 
an Islamic common market and delved into relevant policy issues. Imad A. Ahmad (Bethesda, MD) compared ribā and interest. Abdul Salam Idrisi (Syracuse, NY) proposed a model for an Islamic bank with some difference in emphasis than traditional interest-free banks. Irfan Ul Haq (University of Phoenix, Sacramento, CA) discussed Islam and economic development as regards poverty alleviation and with reference to policies and strategies that have worked, in particular, the two-track strategy of sustainable, labor-intensive economic growth, and investment in people.

The "Women in Islam" panel featured Mary Ali (American Islamic College, Chicago, IL) and Sheema Khan (McGill University, Montreal, PQ, Canada), who spoke on Muslim women. Ali dealt with their perception in American society, while Khan discussed relevant distortions. Zahra D. Buttar (University of Nevada, Las Vegas, NV) read a paper on gender and social interaction, and Arabiyyah Yusuf (McGill University, Montreal, PQ, Canada) documented the contribution of Ramah el-Yanusiah to the early development of education for Indonesian women.

The al Fārūqī Memorial Lecture was delivered by Seyyed Hossein Nasr (University Professor of Islamic Studies, George Washington University, Washington, DC). Entitled "Islamization of Science: Natural, Social, or Otherwise," it argued that Islamization of knowledge is not only possible, but that such social sciences as psychology, sociology, and economics are ready for this. He suggested the following steps: reforming Islamic principles of knowledge, providing an Islamic critique of the present-day crisis, developing awareness of Islam's intellectual tradition, injecting modern sciences into the Islamic worldview both by absorption and rejection, and developing a new paradigm - the Islamic universe of knowledge. In this process, he proposed allowing all views to exist leaving no room for theological or juridical censorship. Furthermore, to truly Islamize a social science like economics, he argued that the Muslim ummah needs to practice its principles through application and policies.

The ninth session had two parallel panels: "Muslim Politics and Islamic Revival," moderated by Mazen Hashim (University of California, Riverside, CA) and "Islamization of Sciences," moderated by Mushtaqur Rahman. In the first panel, Abdullah Sheikh (Washington, DC) evaluated and critiqued Samuel Huntington's "Clash of Civilizations." He rejected Huntington's thesis of the oncoming clash as based on the latter's subscription to a fallacious zero-sum view of power and world domination. He pointed out that civilizations can coexist, live in peace, grow, and prosper if there is general international consensus to seek and live with diversity and dignity. Mumtaz Ahmad spoke on ethnicity and pluralism and noted that modernization has strengthened ethnic and group formations, which has lead to increased conflicts over the prize: power. Lastly, 
Gowher Rizvi (Nuffield College, Oxford University, UK) made an interesting presentation on "Islamic Modemists and Traditionalists: A Case of Mistaken Identity." He argued that Muslim rulers who have been autocratic, denied popular participation, tolerated no opposition, and subservient to western interests (i.e., the Pahlavis of Iran, Mustafa Kemal of Turkey, Mohammad Ali of Egypt) are considered modernizers, whereas Islamist scholars and writers (i.e., Hasan al Banna, Sayyid Qutb, Ali Shariati, Taleqani, and Jalal Al-e-Ahmad), who are anti-imperialist and have criticized the decadence of even some traditional religious figures, have been labeled traditionalists. This, he says, reflects the hegemony of western discourse and the ability of the powerful to define things for others.

The Islamization panel featured Muhammad Akhtar (Slippery Rock State University, Slippery Rock, PA), who spoke on the two-way dynamic process involved in the Islamization of sciences. M. Amir Ali (Institute of Islamic Information and Education, Chicago, IL) discussed "Muslims in America and Social Sciences," and Fahd al-Semmari (Imam Muhammad Ibn Saud University, Riyadh, Saudi Arabia) spoke on his university's role and contribution to the Islamization of social sciences.

The plenary session, "The Islamization of Knowledge: The First Decade," was moderated by Jamal Barzinji. The two presenters were Tāhā al "Alwānī and Mona Abul-Fadl (Director, Western Thought Project, IIIT). Al 'Alwānī raised the issue of rethinking the objectives of knowledge along with recognizing revelation as a basic source of knowledge. He suggested studying knowledge from a tawhìd argued for developing the faculty of critical analysis along with a critical study of the Muslim heritage and modem thought. Mona Abul-Fadl stated that the dominant paradigm of knowledge has a hollow center, whereas the Islamization of knowledge provides a focus of direction towards the human center and leads to the humanization of knowledge and a global view. Thus the tawhìd $i$ episteme plus the humanistic direction called for makes us aware of our own heritage, provides us with a critique of ourselves and others, and helps build bridges with other civilizations.

The banquet keynote speaker, Ali Mazrui (Albert Schweitzer Professor in the Humanities and Director of Global Studies, State University of New York at Binghamton, Binghamton, NY) talked on "Islam and the Debate over the End of History." He raised many questions about the Muslim ummah and its future: Will there be more globalization within the ummah, given that globalism is more developed in Islam than anywhere else? Will Muslims remain passive actors or simply nation-states as in the twentieth century, or will they emerge as an Islamic-Muslim bloc? Which Islam-Islamic civilization will prevail-a liberal one providing freedoms or one occupied with duties, laws, and a legal framework? 
Which way is the Muslim world headed given that nation-states are under pressure due to microlevel retribalization (i.e., the breakup of the Soviet Union and elsewhere) as well as the supra-state movement (i.e., the European Community and the North American Community)?

The twelfth session, chaired by Mohammad Jamal (Concordia University, Montreal, PQ, Canada) had four presentations. Abbes Alkhafaji (Slippery Rock University, Slippery Rock, PA) explored the multiple factors affecting Muslim unity (i.e., nominal adherence to Islam, weak faith, and undemocratic governments). He suggested ways to merge Islam and democracy to bring about representative governments and greater unity. Ishaq al-Qutub (Huron College, London, ON, Canada) analyzed the challenges facing the Muslim ummah and classified them as: providing appropriate interpretations of the Qu'ran and sunnah, the need for Islamic ethical and behavioral standards, the need for learning from western and Muslim history, and developing human resources, technology, education, and self-reliance. Rasha al Disuqi (California Polytechnic State University, San Luis Obispo, CA) dealt with American politics of scarcity and the Nile water as well as the Islamic view of natural resource management. Muhammad Jamal presented the results of "Job Stress among Muslims in North America," which was based on a joint study with Jamal Badawi (St. Mary's University, Halifax, NS, Canada). This involved a sample of Muslims and showed that religiosity was an important moderator of job stress and outcome relationships.

The graduate students panel, moderated by Omar al Talib (University of Chicago, Chicago, IL) featured Muhammad A. al-Ahari Bektashi (EastWest University, Chicago, IL), who spoke on bilingual Islamic education as based on the educational theories of African Muslim slaves in antebellum America. The second speaker was Suhaib Barzinji (University of Maryland, College Park, MD), who discussed "The Islamic Worldview and the Contemporary Concept of Mass Media." He covered various aspects of mass media operation, norms, and ethics in an Islamic state.

The last session, the General Body Meeting, was presided over by Dilnawaz Siddiqui. Sayyid M. Syeed and Mohammad Abu Gidieri (Treasurer, Sterling, VA) presented their reports. The creation of an endowment so that the AMSS can continue to function as a financially independent institution was discussed. The complete proceedings of the previous year's annual conference were also made available.

Irfan Ul Haq Adjunct Faculty in Economics University of Phoenix Sacramento, California 